\title{
A concepção de um país: o pensamento nacionalista de Serzedello Correa *
}

\author{
Ivan Colangelo Salomão
}

\begin{abstract}
Resumo
Os primórdios do nacionalismo brasileiro remontam ao século XVII, cuja influência em distintos movimentos políticos no Brasil colonial fez-se notória. A envergadura alcançada pelo nacionalismo após a Independência merece análise pormenorizada, contudo, não apenas por seus desdobramentos políticos, como a proclamação da República, mas devido, principalmente, à formação posterior de uma estratégia político-econômica eminentemente brasileira, o nacional-desenvolvimentismo. Neste contexto, figuras como a do general Serzedello Correa em muito contribuíram para a formação e a formatação de um pensamento econômico original na periferia do sistema capitalista.
\end{abstract}

Palavras-chave: Nacionalismo; Liberalismo; Brasil - Século XIX; Correa, Serzedello (1858-1932).

\section{Abstract \\ The conception of a country: Serzedello Correa's nationalist thinking}

The origins of Brazilian nationalism, whose influence on different political movements in colonial Brazil became notorious, dates back to the seventeenth century. The scale achieved by nationalism after independence deserves detailed analysis, however, not only because of political developments, such as the proclamation of the Republic, but mainly due to the subsequent formation of an eminently Brazilian political-economic strategy, national-developmentalism. In this context, figures such as general Serzedello Correa contributed greatly to the formation and formatting of an original economic thought in the periphery of the capitalist system.

Keywords: Nationalism; Liberalism; Brazil $-19^{\text {th }}$ century; Correa, Serzedello (1858-1932).

JEL B31.

\section{Introdução}

A historiografia tradicionalmente reserva a alcunha desenvolvimentista tanto em sua fase nacionalista, quanto na associada ao capital estrangeiro - à política econômica empregada após a década de 1930, em especial, aos governos Getúlio Vargas e Juscelino Kubitschek. Do ponto de vista da experiência histórica, há, portanto, relativo consenso entre os analistas de que se trata, o desenvolvimentismo, de um fenômeno vivenciado no século XX.

O fato histórico não pressupõe, contudo, concomitância com seu corpo teórico subjacente. Ainda que o conjunto destas medidas tenha sido, de fato, levado

\footnotetext{
* Artigo recebido em 3 de dezembro de 2014 e aprovado em 1 de novembro de 2016.

** Professor Adjunto da Faculdade de Ciências Econômicas e do Programa de Pós-Graduação em Economia da Universidade Federal do Rio Grande do Sul (PPGE-UFRGS), Porto Alegre, RS, Brasil. E-mail: ivansalomao@gmail.com.
} 
a cabo somente após o fim da República Velha, as evidências apontam que, ao menos no plano das intenções, o desenvolvimentismo havia muito se pronunciava no meio jornalístico, militar e, em especial, no ambiente político.

A mais antiga vertente formadora do pensamento desenvolvimentista foi a composta pelos atores nacionalistas, cujas primeiras manifestações remontam ao período colonial. Este nacionalismo embrionário se expressava, em aquele período, através de revoltas regionais que se opunham a toda opressão inerente ao exclusivo metropolitano. E foi justamente este caráter localista que as impediu de serem caracterizadas, neste primeiro momento, como um processo consciente e de envergadura coletiva ${ }^{1}$.

Se durante a vigência do colonialismo as rebeliões nacionalistas estiveram envoltas em uma aura política - com destaque para os levantes que antecederam a chegada da Corte portuguesa e o consequente rompimento do monopólio colonial -, foi a partir do início do Segundo Reinado que o movimento incorporou um viés mais econômico em suas reivindicações, substituindo o antigo inimigo externo pelo embate contra os grupos sociais que aqui o representavam ${ }^{2}$.

A despeito da saliente intersecção com causas paralelas observada no decorrer do regime imperial, o nacionalismo ainda não pressupunha necessária a industrialização. Conquanto as pautas destes dois grupos pudessem ser coadunadas em diferentes situações, observar-se-á que a quantidade não desprezível de nuances entre ambas recomenda ao analista a separação metodológica dos temas até, pelo menos, meados do século XX. É neste sentido que Lima (1988, p. 71) afirma ter havido não apenas um tipo de nacionalismo, mas, sim, várias de suas versões.

Foi nesse contexto, portanto, que surgiram figuras como a de Innocencio Serzedello Correa, militar cuja destacada atuação política e intelectual fez de seu nome uma das principais lideranças nacionalistas no alvorecer republicano. A conjuntura econômica do período em que Correa ocupou alguns dos mais elevados

(1) A eclosão das primeiras manifestações nacionalistas respondeu a motivações diversas no decorrer da história do Brasil; da luta contra a escravatura à insatisfação com a baixa qualidade de vida da população nativa. Ainda assim, a concatenação cronológica do transcorrer histórico faz com que tais eventos tornem-se passíveis de alguma sistematização metodológica. A periodização oferecida por Sodré (1960, p. 12) corrobora este entendimento ao pressupor em três os distintos momentos do nacionalismo brasileiro: os levantes que precipitaram a Independência, a movimentação que precedeu a proclamação da República e, por fim, a articulação que desembocou na chamada "Revolução brasileira" de 1930. Não obstante tenham se restringido a agitações pontuais no tempo e no espaço, não se deve negligenciar a contribuição das chamadas revoltas nativistas para o despertar da consciência nacional. Ao se oporem, na maioria das vezes, à opressão tributária e ao sistema de privilégios atinente ao mercantilismo português, várias foram as tentativas de se contrapor ao poder discricionário com que a Coroa tolhia o desenvolvimento da economia brasileira.

(2) Neste sentido é que Lessa (2008, p. 243) reitera a funcionalidade da ameaça estrangeira para o fortalecimento da retórica nacionalista: "A mais óbvia matriz de nacionalismo surge quando, sendo necessário para o Estado Nacional defender território e povo, é alavancado o temor, ou seja, o nacionalismo surge como escudo, alimenta a sensação de pertinência a um corpo especial, para o popular ameaçado em seus direitos". 
cargos públicos do país - quando a monocultura de exportação já demonstrava ser incapaz de reverter os recorrentes déficits externos - reforçou a convicção do autor na possibilidade de se desenvolver os demais setores da economia nacional de modo sistêmico.

\section{Serzedello Correa: apontamentos biográficos}

Innocencio Serzedello Correa nasceu em Belém do Pará, em 16 de junho de 1858. Filho de portugueses pertencentes à elite aristocrática de Lisboa, ficou órfão de pai ainda em tenra idade, momento a partir do qual sua família passou a viver sob constante restrição financeira. Auxiliado por meio de contatos pessoais, ingressou na mais prestigiada entidade de ensino da capital paraense, o Seminário Menor da Diocese, onde concluiu o ciclo de educação básica.

Em 1874, ainda adolescente, mudou-se para o Rio de Janeiro com o objetivo de ingressar na Escola Militar da Corte, onde veio a formar-se engenheiro militar e mestre em Ciências Físicas e Biológicas ${ }^{3}$. Diplomado, tornou-se professor da mesma instituição, na qual lecionou diversas disciplinas nas áreas de exatas e biológicas ${ }^{4}$. Serzedello ainda retornou à carreira docente nos últimos anos de sua vida, quando assumiu a cátedra de Economia Política da Faculdade de Direito do Rio de Janeiro.

A instrução marcial alcançou dimensão que extrapolava sua formação acadêmica. Foi na Escola Militar que Correa conheceu o professor e seu futuro mentor intelectual, o general Benjamin Constant Botelho de Magalhães, cuja influência expressar-se-ia na defesa da causa abolicionista, nas convicções positivistas e, principalmente, na postura nacionalista que o autor imprimiu à sua ação política.

"Incontrolavelmente" republicano ${ }^{5}$, Serzedello teve participação fundamental no golpe militar que derrubou o Império ${ }^{6}$. Designado para articular o

(3) Graduado com mérito, Serzedello conquistou a admiração de Benjamin Constant ao responder com desenvoltura incomum as perguntas realizadas pelo mestre na banca da disciplina de Mecânica Racional. Em homenagem ao desempenho do pupilo, Constant decretou feriado na escola após a avaliação de Correa: "É o exame mais belo e profundo a que tenho assistido depois que sou professor na Escola Militar" (Pinheiro, 2008, p. 10).

(4) Durante visita realizada à escola, em 1885, o imperador assistiu à aula de Biologia ministrada por Serzedello Correa. Ao final da exposição, que ultrapassara a duração regulamentar por solicitação do monarca ("Guarde seu relógio, comandante. Preleções como esta, ouvem-se sem cogitar do tempo"), D. Pedro afirmou que não conhecera docente mais qualificado do que o militar paraense: "Ouvi na Europa muitas conferências de professores de renome universal, porém nunca ouvi uma só mais brilhante, mais clara e mais bela do que esta lição". Em retribuição, ordenou o soberano que o presenteassem com o que desejasse o professor (Pinheiro, 2008, p. 11).

(5) Serzedello Correa pertencia à "ala dos namorados" da República, homens que, por ela, arriscariam a vida. Em determinada ocasião, questionado pelo imperador se ainda mantinha a fervorosa convicção republicana, respondeu-lhe orgulhosa e laconicamente: "Muito, majestade" (Fontoura, 1959, p. 13).

(6) Dentre os motivos que explicariam a deposição do Império pelo Exército, liderado pelo mais monarquista de seus generais, Saes (2011, p. 36) aponta para duas prováveis causas: (1) a divergência entre a ideologia meritocrática das Forças Armadas e o patriarcalismo do regime monárquico, cuja gestão era considerada arcaica pelos militares; e (2) a existência de um já encorpado projeto político próprio - nacionalista, intervencionista e industrializante - no seio militar. 
levante com a Marinha - Força que, às vésperas do motim, ainda não havia aderido totalmente ao movimento -, Correa coordenou os últimos arranjos durante o célebre baile da Ilha Fiscal, uma semana antes da deposição do regime.

Na manhã do dia 15 de novembro de 1889, marchou junto com Deodoro da Fonseca e outros militares republicanos (como Sólon Ribeiro, Sena Madureira e o próprio Benjamin Constant) sobre o Campo de Santana, onde depuseram o Visconde de Ouro Preto e proclamaram a República. Diante da sucumbência pacífica do último chanceler do Império, Correa foi escalado pelo marechal a escoltar os líderes monarquistas a fim de garantir-lhes a integridade física.

Sob o regime republicano, a carreira de Serzedello Correa suplantou os quartéis para adentrar a arena política. Em 1890, foi nomeado governador do Paraná e eleito deputado constituinte por seu estado natal no final do mesmo ano. Foi conduzido à Câmara Federal ainda em outras três oportunidades, representando as províncias do Rio de Janeiro (1895), do Mato Grosso (1906) e, novamente, do Pará (1902 e 1912).

Foi no governo de Floriano Peixoto, porém, que Serzedello alcançou o auge de sua trajetória política, ocupando quatro ministérios em um período inferior a dois anos: Relações Exteriores (02/1892 - 06/1892), Agricultura e Viação (06/1892 12/1892), Fazenda (08/1892 - 04/1893) e Justiça e Interior (interino). Sob a presidência de Nilo Peçanha, por fim, tomou posse como prefeito do Distrito Federal em julho 1909, cargo que ocupou até novembro do ano subsequente.

À testa da primeira pasta, liderou o contencioso territorial com a Argentina na questão das Missões, oportunidade em que introduziu o jurista José Maria Paranhos (o Barão do Rio Branco) na diplomacia internacional ao nomeá-lo como o representante brasileiro na disputa. Além disso, assinou tratados de comércio com a França e Alemanha, e estabeleceu as diretrizes dos acordos ulteriormente consagrados com os Estados Unidos e Portugal. Já na célere passagem pela pasta da Agricultura e Viação, seu principal legado foi o início das obras de modernização do porto de Santos, responsável pelo escoamento de grande parte do café produzido no oeste paulista.

Meses após ter sido exonerado do Ministério da Fazenda, Serzedello Correa enfrentou, em setembro de 1893, seu mais dramático revés político. Mesmo não tendo se envolvido diretamente na articulação da Revolta da Armada, a relação já desgastada com o marechal Floriano Peixoto rendeu-lhe nove meses de encarceramento. A recusa em sublevar-se contra os marinheiros revoltosos liderados pelo almirante Custodio de Melo - amigo pessoal de Serzedello e principal oponente militar de Floriano - foi explicada através da mesma carta em que encaminhou seu pedido de demissão do Exército, instituição à qual retornaria apenas na primeira década do século XX (Rego, 1989). 
Além da trajetória militar, acadêmica e política, Correa atuou ainda como um dos principais líderes industrialistas ao longo das três primeiras décadas republicanas, embora jamais tenha sido um empresário propriamente dito. Presidente da Sociedade Auxiliadora da Indústria Nacional nos últimos dois anos de existência da instituição, tornou-se o primeiro dirigente do Centro Industrial do Brasil, fundado em 1904, cargo que ocupou por oito anos consecutivos. Afastado da vida pública desde meados da década de 1920, faleceu no Rio de Janeiro, em 1932, aos setenta e quatro anos de idade.

\section{Liberalismo e nacionalismo no Brasil agrário-exportador}

O surgimento do nacionalismo moderno, e mais especificamente, a formação dos Estados nacionais estiveram diretamente associados aos interesses da burguesia mercantil europeia, a qual requeria proteção ao comércio e garantia à propriedade privada. O princípio da regulamentação econômica embasava o monopólio colonial, assegurando ao capital comercial o acesso a mercados mais amplos e seguros. A expressão teórica da aliança entre a nascente classe burguesa e o Estado foi o mercantilismo (Costa, 1982).

Com a ascensão do capitalismo industrial e a consequente crise do sistema colonial, o conceito de nacionalismo na América foi remodelado. Naquele momento, nacionalismo e liberalismo ainda não se opunham, como se verificaria mais tarde; antes, caminhavam juntos. $\mathrm{O}$ nacionalismo americano expressava, em primeiro lugar, a necessidade de rompimento dos laços com as metrópoles europeias. Mas também representava o repúdio às leis, regulamentações, concessões e outras instituições inerentes ao sistema mercantilista. Eis o ponto de tangência, ainda que fugaz, de duas ideologias que viriam a se contrapor em todo o continente (Fonseca, 2004).

A incorporação das ideias liberais que pululavam na Europa iluminista passou a dividir a elite intelectual do país recém-emancipado de forma paulatina. A evolução inerentemente dialética do pensamento fez com que o nacionalismo brasileiro surgisse em um ambiente no qual imperava a sua futura negação, o liberalismo.

Neste sentido é que o debate acerca da adaptação das ideias liberais no Brasil galgou a atenção de distintos analistas, especialmente a partir dos anos 1970. A célebre citação de Sérgio Buarque de Holanda preanunciava a controvérsia em que se envolveria a questão: "Trazendo de países distantes nossas formas de vida, nossas instituições e nossa visão do mundo e timbrando em manter tudo isso em ambiente muitas vezes desfavorável e hostil, somos uns desterrados em nossa terra" (Holanda, 2006, p. 19). 


\subsection{As ideias estavam no lugar?}

A adequação do ideário liberal à realidade de um país em que predominavam instituições diretamente ligadas ao regime monárquico dividiu os autores que se dispuseram a analisar o tema, cuja polêmica a ele subjacente auferiu novos contornos a partir do artigo seminal de Schwarz ([1973] 2001).

Ideologia adotada pela burguesia europeia que se levantava contra o sistema de privilégios do Ancien Régime, o liberalismo expressava as aspirações de uma classe interessada em organizar a sociedade em bases novas, restringindo o arbítrio do monarca e organizando o Estado de forma a representar os seus interesses ${ }^{7}$. Em última instância, a burguesia buscava eliminar as barreiras que impossibilitavam o desenvolvimento do nascente capitalismo industrial, cuja vitória política se deu com a Declaração dos Direitos do Homem e do Cidadão, em 1789.

Importadas sem filtros, tais ideias não encontraram nos trópicos a coesão da estrutura socioeconômica europeia, tornando-se, assim, incapazes de romper com os laços e valores tradicionais. Adotado pela oligarquia agroexportadora e pelos setores ligados ao comércio importador, o liberalismo brasileiro esbarrava na manutenção do regime "a ser deposto" para locupletar-se, aqui, como uma ideologia de fato. Nos termos empregados por Schwarz ([1973] 2001), havia uma "sensação quase tangível" da inadaptabilidade dessas ideias ao ambiente brasileiro. Daí, portanto, estarem fora de lugar.

Para além de todos os seus desdobramentos, a consagração de um governo imperial após a emancipação política de 1822 respondia, por si só, pela inadequação que o ideário iluminista experimentaria no Brasil. O escravismo, por sua vez, expressava sua mais eloquente contradição, uma vez que o cativeiro desmentia as ideias liberais ao negar sua premissa mais elementar.

O descasamento entre o liberalismo europeu e a realidade brasileira manteve-se presente mesmo após a abolição da escravatura e o advento republicano. Para Schwarz, a "ideologia do favor" - o segundo elemento delineador de sua tese conservou a base da estrutura social vigente desde a emancipação política. Em amplo sentido, do favor é que dependia a sobrevivência material da vasta camada de homens livres: "Assim, com mil formas e nomes, o favor atravessou e afetou no conjunto a existência nacional" (Schwarz, [1973] 2001, p. 5).

Tratava-se da arbitrariedade subjacente ao favor o elemento responsável pela inaplicabilidade do liberalismo no Brasil. Instituição de aceitação "quase universal”,

(7) As reivindicações da burguesia poderiam ser resumidas nos seguintes pontos: direito de propriedade, isonomia perante a lei e liberdade de representação política. Ou então, nas palavras de Schwarz ([1973] 2001, p. 5), "a autonomia da pessoa, a universalidade da lei, a cultura desinteressada, a remuneração objetiva e a ética do trabalho". 
era tão incompatível com as ideias liberais quanto o escravismo, pois as absorvia e as deslocava, gerando, assim, "um padrão particular". Praticando a exceção à regra, o favor atribuía "independência à dependência, utilidade ao capricho, universalidade às exceções, mérito ao parentesco, igualdade ao privilégio" (Schwarz, [1973] 2001, p. 7).

O autor associa esta realidade à "desfaçatez" da classe dominante, sugerindo que os países periféricos teriam que tomar emprestado dos centrais determinadas formas - como, por exemplo, o romance, o sistema parlamentar e as normas jurídicas - que os tornassem mais "civilizados". Ainda que não pudessem ser integralmente praticadas, as ideias liberais eram, ao mesmo tempo, indescartáveis, pois se prestavam a conferir um verniz erudito à "envergonhada e rancorosa" elite tropical. Adotado com orgulho e de forma ornamental, o liberalismo servia como prova de modernidade e distinção de uma elite apegada a práticas políticas e sociais retrógradas (Bentivoglio, 2002).

Na visão de Ricupero (2008), a tese de Schwarz não expressaria um fato - a inadequação de certas referências intelectuais a um dado contexto social - mas indicaria um processo de formação, que se completaria na forma. Implícito a esse movimento, encontrava-se a aspiração de se superar a situação de subordinação colonial, estabelecendo-se um quadro de maior autonomia o qual identificaria o surgimento da nação recém-emancipada.

Já para os que se opõem à tese da inadequação do liberalismo no Brasil, não haveria sentido em classificar tais ideias como deslocadas de seu ambiente original devido à funcionalidade por elas revelada como instrumento de combate ideológico: em um primeiro momento, o ideário liberal foi empregado na luta contra o sistema colonial; lograda a Independência, passou a justificar a crescente hegemonia dos latifundiários ligados ao setor exportador.

É neste sentido que Franco (1976), uma das primeiras analistas a contestar a análise de Schwarz, envolve o debate no processo de evolução da economia capitalista. Para a autora, o conceito de liberalismo surgiu com a dominação econômica imposta pela nascente burguesia industrial, cumprindo, portanto, a sua utilidade ad hoc aos que dele se utilizavam para justificar suas posições.

Baseada na dicotomia em que se assenta a teoria da dependência, a autora sustenta que tanto o centro quanto a periferia favoreceriam o processo de constituição e de reprodução do capital, distanciados, apenas, pelo tempo e pelo espaço. Compondo o mesmo sistema de produção, ambos os polos carregariam seu conteúdo essencial - o lucro -, não havendo, pois, contradição na adoção do liberalismo no Brasil escravocrata:

Assim como todos os seus predecessores, insistindo na originalidade da combinação brasileira de capitalismo e escravidão, país colonial e país 
burguês, Roberto [Schwarz] seria vítima da mesma miragem ao imaginar que uma 'diferença essencial' distingue as nações metropolitanas, sedes do capitalismo, núcleo hegemônico do sistema, dos povos coloniais, subdesenvolvidos e periféricos (Franco, 1976).

Corrobora este entendimento a análise tecida por Fernandes (1987). Ao internalizar os centros de poder e nativizar os círculos sociais que os controlavam, a Independência pressupunha dois elementos dialéticos: o revolucionário, representado pela ruptura do estatuto colonial; e o conservador, evidenciado pelos propósitos de preservar e fortalecer uma ordem social que respeitasse os interesses das elites nativas. Assim sendo, a absorção do liberalismo por parte dos grupos os quais encabeçaram aquele movimento esteve na origem das concepções que impulsionaram os conflitos com o Reino, assumindo um "nítido caráter instrumental". Diversamente do que se proclamava, conclui o autor que o liberalismo exerceu influências sociais construtivas em várias direções concomitantes, não podendo ser aqui caracterizado como "postiço, farisaico ou esdrúxulo" (Fernandes, 1987 , p. 35).

Para esses autores, portanto, a suposta contradição entre escravismo e liberalismo no contexto agrário-exportador não passou de um oximoro. As interpretações de Franco (1976) e Fernandes (1987) são consubstanciadas quando se distinguem os conceitos de liberalismo político do econômico, como posteriormente o fizeram diferentes analistas, dentre os quais Coutinho (1976) e Bosi (2001). Conforme ressalta este autor, coube à retórica escravista demonstrar que a ideologia da doutrina clássica poderia aplicar-se perfeitamente à realidade brasileira. Indo além, argumenta Bosi que a origem geográfica ou cronológica das ideias não determina para todo sempre seu destino e seu valor, relativizando, assim, a tese de Schwarz.

A contribuição dessa leitura intermediária aponta para a plasticidade com que o conceito de liberalismo foi absorvido pela elite agrária brasileira: economicamente liberal, propugnava as vantagens ricardianas da especialização produtiva; politicamente conservadora, rejeitava, coerentemente, a liberação do cativeiro, configurando uma ideologia classificada por Bosi (2001, p. 212) como "liberal-escravista".

Diversos analistas ratificam o entendimento de que teria sido possível a coexistência harmônica do pensamento liberal com uma sociedade escravocrata. De acordo com Rouanet (1991), por exemplo, o liberalismo brasileiro só poderia ser interpretado à luz da realidade política, econômica e social do Brasil, assinalando a familiaridade com que as elites locais conviviam com este suposto contrassenso. Já para Nogueira (1984), as ideias não estariam fora de lugar pela adaptação a que se submeteram ao desembarcarem em um ambiente não apenas de pensamento, mas, principalmente de práticas políticas e sociais conservadoras. 
Isto posto, faz-se prudente ressaltar que, durante o período colonial, nacionalismo e liberalismo não se opunham necessariamente, como viria a ocorrer a partir de meados do século XIX; ao contrário, compunham, naquele momento, as faces de uma mesma moeda, conforme será apresentado a seguir.

\subsection{O nacionalismo liberal}

Fora de lugar ou não, o fato é que, desde meados do século XVII, diversos foram os atores que aqui representavam e verbalizavam os interesses dos grupos diretamente relacionados ao ideário liberal. Introduzido no Brasil através do Correio Braziliense, editado em Londres por Hipólito José da Costa, o liberalismo tropical teve em Silvestre Pinheiro Ferreira seu primeiro teórico brasileiro e em José Bonifácio de Andrada seu mais ilustre defensor político.

Desde as suas primeiras manifestações, o liberalismo brasileiro subdividiuse em três diferentes vertentes ${ }^{8}$. Os eventos que culminaram na emancipação do país representaram as primeiras expressões liberais do século XIX. As revoltas que eclodiram no decênio compreendido entre as décadas de 1830 e 1840 marcaram a segunda fase do movimento liberal, cujo ápice político deu-se com as rebeliões do período regencial. O terceiro estágio precedeu a instauração do regime republicano, quando a ideologia já havia absorvido aspectos da causa nacionalista.

Macedo (1997) sistematiza os diferentes momentos por que passou o liberalismo no Brasil independente, classificando-os como radical, doutrinário e cientificista. O primeiro grupo, republicano e nacionalista, indispunha-se, primordialmente, contra o alegado despotismo de D. Pedro I. Com efeito, suas principais bandeiras circunscreviam a oposição aos privilégios de que gozavam os portugueses recém-instalados no Rio de Janeiro. Frei Caneca, Cipriano Barata, Diogo Feijó e Teófilo Otoni foram seus mais importantes protagonistas. Resultado direto da atuação desses personagens, a formação do Partido Liberal, na década de 1840, viria a consagrar, ainda que apenas no epíteto, a ideologia liberal.

O segundo grupo, cujo lema "liberdade com ordem" denotava o seu viés conservador, notabilizou-se pela parcimônia de suas proposições. Suas principais causas podiam ser resumidas na defesa de uma monarquia constitucional, na descentralização administrativa e na subordinação da igualdade à liberdade. Justiniano José da Rocha, Bernardo Pereira Vasconcelos e Paulino Soares de Souza (o Visconde do Uruguai), foram os seus representantes mais notáveis. Reticentes em

(8) Já para Carvalho (1990), eram duas as principais linhagens do liberalismo existentes no Brasil até a proclamação da República: a propagada pelos Estados Unidos, baseada em Montesquieu, e a oriunda da França, que tinha em Rousseau seu principal ideólogo. Quando do advento republicano, por sua vez, três foram as ideologias que disputaram o poder: o liberalismo à americana, o jacobinismo francês e o positivismo. 
relação à causa escravista, perderam influência conforme a bandeira abolicionista galgava posições no parlamento e na sociedade.

O terceiro movimento liberal observado no Brasil imperial fortaleceu-se após a onda nacionalista que se espraiou pelo país após a Guerra do Paraguai (18641870 $)^{9}$. Ao extrapolar as questões de cunho político, o grupo trazia novos temas para o debate intelectual, voltando-se para as temáticas social, econômica, religiosa, entre outras. Republicanos moderados, lutavam por causas como o federalismo, o abolicionismo, a educação básica e o laicismo do Estado. Compuseram este grupo, entre outros nomes, figuras como as de Gaspar Silveira Martins, Aureliano Cândido Tavares Bastos, Tobias Barreto, Joaquim Nabuco, Sílvio Romero e Clóvis Bevilácqua. Após a promulgação da Constituição de 1891, de forte viés positivista, os liberais cientificistas perderam paulatinamente a influência de outrora, tendo sobrevivido praticamente no ostracismo até o fim do Estado Novo (Macedo, 1997).

Liberais ou autoritários, contemporâneos ou porvindouros, o fato é que, em comum, os atores e autores nacionalistas acima apresentados influenciaram e foram influenciados pelo pensamento de Serzedello Correa, cuja trajetória intelectual será analisada a seguir.

\section{0 pensamento nacionalista de Serzedello Correa}

A visão nacionalista, concebida quando do contato com os oficiais positivistas da Escola Militar, expressava-se em Serzedello Correa com traços quase chauvinistas. A convicção de que o Brasil poderia tornar-se uma nação desenvolvida condicionava-se, apenas e tão somente, à adoção de políticas "sensatas" e condizentes com a realidade de um país novo e subalterno. O percurso histórico por que passaram as economias europeias legitimava a sua esperança: "Não é, pois, o sentimento nativista que me anima, e sim um alto sentido de patriotismo, que eu mesmo admiro em estrangeiros" (apud Machado, 1972, p. 130).

Dentre as mais relevantes características de seu pensamento econômico destacam-se a visão harmônica da estrutura produtiva brasileira, a defesa intransigente da nacionalização das riquezas naturais capitaneada pelo Estado e o apoio enfático à causa industrial via, mormente, proteção alfandegária.

\subsection{Nacionalismo e intervenção estatal}

A necessidade de se libertar da dependência econômica em relação aos países centrais caracteriza a diretriz do pensamento de Serzedello Correa. Para romper com a dominação a que se submetia o Brasil, o autor considerava obrigatória

(9) A conflagração concorreu, de fato, para reforçar um ainda hesitante sentimento nacional. A manutenção do sistema escravista após a vitória militar, entretanto, anulou grande parte dessa aura coletivista surgida a partir do triunfo das tropas (Carvalho, 1990). 
a nacionalização das riquezas pátrias. Se livre politicamente ${ }^{10}$, o país ainda não havia logrado a sua autonomia material e produtiva devido à aceitação de ideologias estrangeiras que se lhe entravam pelos portos ${ }^{11}$ : "Na ordem dos interesses econômicos somos, ainda hoje, uma colônia" (Correa, 1903, p. 19). A trajetória do país pós-1822 era descrita pelo autor como a de "uma nação que fez a sua emancipação política e que, dia a dia, mais e mais, apertou os laços de colônia que a prendiam ao estrangeiro" (Correa, 1903, p. 23).

Diante "deste estado de coisas" é que se fazia não apenas conveniente, mas indispensável que o governo brasileiro adotasse uma "política econômica sábia, prudente, criteriosa, mas profundamente nacional” (Correa, 1903, p. 24, grifos meus). Nacional e obrigatoriamente capitaneada pelo Estado. Correa contestava a viabilidade de o desenvolvimento econômico dar-se através da livre atuação das forças de mercado, cabendo ao ente público, portanto, nortear este processo.

Ainda que por vezes reducionista, a divisão metodológica por ele oferecida evidencia de modo esquemático a sua concepção de política econômica. Serzedello classificava os modelos de Estado em três tipos: socialista, individualista e eclético. A recusa aos dois primeiros baseava-se em motivos de origem comum - a veemência com que ambas as doutrinas rechaçavam o polo oposto do sistema: no socialismo, todas as responsabilidades recairiam sobre o Estado; já para os individualistas, as forças de mercado deveriam sobrepujar-se às estatais, reduzindo-as a uma posição quase figurativa ${ }^{12}$.

A adoção do ecletismo justificar-se-ia pelo equilíbrio com que se situava entre as outras duas escolas. Assim como a planificação absoluta esbarrava em impedimentos práticos, a atuação do livre-mercado tampouco se mostrava adequada a economias subdesenvolvidas, restando ao "Estado disciplinador", pois, contrapesar esta relação: "Nos povos novos, a iniciativa individual é muitas vezes fraca, e a ação do Estado precisa se fazer sentir para realizar melhoramentos necessários à vida humana". Concluindo de modo relativamente simplista, considerava o comedimento

(10) Serzedello sustentava que o "Brasil, país novo" e que ainda não se livrara da condição de colônia, deveria, através de instrumentos públicos, concluir o seu processo de desenvolvimento levado pelas mãos do Estado. Para Correa, o Império havia realizado as "tarefas políticas"; caberia ao novo regime, portanto, o encargo de completá-las do ponto de vista econômico (Corrêa, 2008).

(11) Convicto de que o liberalismo europeu não se adequaria às necessidades das economias periféricas, o autor procurava justificar o atraso destes países à aceitação da ideologia estrangeira: "A nossa nacionalidade constituiu-se em período em que errôneas e falsas doutrinas sobre a indústria comercial tinha foros de cidade" (Correa, 1903, p. 76).

(12) Muito embora rechaçasse a capacidade de o mercado alocar de modo eficiente os recursos disponíveis, Correa reconhecia os proveitos da livre iniciativa dos agentes racionais: "De todas as forças econômicas, o mais importante é o indivíduo" (Correa, 1919, p. 16). Além disso, mostrava-se um defensor enfático da propriedade privada, afirmando que se tratava de "um bem natural e de grandes vantagens para a humanidade. A ciência prova que ela está de acordo com a natureza humana. [...] A propriedade individual é a base da civilização humana" (Correa, 1919, p. 23). 
do ecletismo um "meio termo [...] onde parece residir a verdade" (Correa, 1919, p. 19).

Caso atuasse "sem a estreiteza da escola individualista e sem os exageros das teorias socialistas", o Estado representaria "um vigoroso elemento de progresso material" (Correa, 1903, p. 24). Além da necessária ação supletiva na área social incumbência exclusiva do ente público -, o planejamento estatal, condição sine qua non para o desenvolvimento, era descrito pelo autor como uma "grande força econômica que deve governar a sociedade e presidir os seus destinos de acordo com a vontade nacional" (Correa, 1919, p. 47). A relevância da intermediação estatal permeava a arquitetura de seu pensamento econômico:

Sem um plano geral, sistemático e persistentemente executado por largos anos e que obedeça à preocupação de desenvolver as nossas fontes de produção, amparar e proteger nossas indústrias e nacionalizar uma grande parte dos lucros que o exercício da atividade comercial e industrial vai criando entre nós, impossível será dar solução ao problema econômico (Correa, 1903, p. 22).

A proposta de nacionalizar as riquezas do país encontrava na remessa de lucros ao exterior o seu mais saliente adversário. Ao defender o seu projeto de lei que regulamentava o envio desses recursos, afirmava o autor que " $85 \%$ dos lucros da atividade comercial não nos pertenciam", porcentagem ainda inferior aos recursos expatriados por diversos outros setores, como os de transporte marítimo, financeiro e, principalmente, das companhias de seguro (Correa, 1903, p. 22).

A repulsa às condições favoráveis oferecidas às empresas estrangeiras de seguro compunha o cerne de sua luta pela nacionalização de lucros. Definidas por ele como "verdadeiras bombas de sucção de toda a economia pátria" (Correa, 1903, p. 86), a proposta de Correa sugeria que estas companhias se submetessem ao mesmo tratamento tributário imposto às nacionais, de modo que aquelas não mais gozassem de "vantagens atentatórias ao nosso amor próprio, ao nosso patriotismo, aos nossos brios. Excelência, nós não somos a Beócia!", exclamava em mensagem enviada diretamente ao ministro da Fazenda da época (Correa, 1903, p. 84).

Outro setor que também deveria passar obrigatoriamente pela regulação estatal era o dos recursos naturais, cuja abundância no subsolo brasileiro não isentava o país de ser um grande importador de minérios. A participação do Estado na exploração mineral far-se-ia ainda mais conveniente tendo-se em vista a necessidade latente de acumulação de lastro - mais especificamente, de metais preciosos - por parte das autoridades monetárias. A parcimônia da sua proposta de nacionalização dos lucros aqui auferidos poderia ser sucintamente resumida nos dizeres do próprio autor: o que se propunha era, simplesmente, a "incorporação lenta, segura e contínua de todos esses elementos que nos vem do exterior, por um conjunto de medidas que 
criem óbices à remessa para fora de todas as nossas economias, que tenham o poder de ir aclimando aqui parte dos lucros" (Correa, 1903, p. 72).

Não obstante clamasse explicitamente contra a dominação econômica imposta pelos países industrializados, Correa não adotava um discurso exatamente xenófobo ${ }^{13}$. Ciente da relevância do capital financeiro internacional para o desenvolvimento da produção brasileira, aquiescia ao emprego adequado destes recursos no país: "Bem sei que um país novo precisa do elemento estrangeiro, especialmente o português, o qual nos traz trabalho e capitais" (Correa, 1903, p. 72).

Em que pese a aparente contradição que o autor mantinha em relação ao capital forâneo, é neste sentido que se faz original a sua luta pela industrialização do Brasil, por ele empunhada nas diversas arenas que ocupou ao longo de sua trajetória política e intelectual.

\subsection{Industrialização e subdesenvolvimento}

Dentre as diferentes causas que apontavam para um objetivo correlato ao que movia os atores nacionalistas, tratou-se a industrialização de uma das principais bandeiras defendidas pelo general ao longo de sua vida pública. Escopo, este, que haveria de ser alcançado, mais uma vez, através da intervenção do Estado.

Serzedello Correa atuou, desde meados da última década imperial, como um elo entre os industriais e a oficialidade militar, cuja campanha pela industrialização remontava aos anos 1860, quando a defesa extemporânea de uma política de proteção tarifária já se fazia presente nas páginas de periódicos como O Militar (Saes, 2011).

A rejeição à propalada vocação agrária do país resume de modo sucinto o eixo de seu pensamento. Ao contrapor-se ao pretenso antagonismo entre as causas da indústria e da agricultura, Correa condenava a concepção - a qual "ninguém se arriscava a contestar e de valor, por assim dizer, axiomático" - de que o Brasil era um país essencialmente agrícola (Correa, 1903, p. 144). Indo além, o autor tampouco consentia com a dicotomia excludente entre as indústrias ditas naturais e artificiais: "Devo afastar a ideia corrente em muitos espíritos de que só devemos amparar o que chamam eles indústrias naturais - isto é, indústrias que têm em nosso país a matéria-prima. [...] Indústria natural é um contrassenso" (Correa, 1903, p. 130). Tratava-se, esta, da posição adotada pelos próprios empresários, os quais propalavam não apenas a possível afinidade entre ambos os ramos produtivos, como também

(13) Remetendo-se à exaustivamente citada "segunda independência" de que carecia o país, Correa não propunha um conflito aberto com os países centrais, mas apenas o entendimento de que se tratava a competição internacional de um fato inevitável: "Os nossos antepassados fizeram a nossa independência política e nos legaram o problema da nossa independência econômica, que temos comprometido e não sabemos resolver. Não é combatendo o estrangeiro, não é mantendo o fermento de ódios que nos dividem que o conseguiremos. É entrando em concorrência com ele, mas pelo trabalho inteligente” (apud Backes, 2011, p. 103). 
isentavam a nascente (e pouco eficiente) indústria brasileira pela carestia de vida que assolava a população (Leme, 1978).

A despeito do zelo que dedicava à produção agrícola, Serzedello não a julgava capaz de, num primeiro momento, solucionar os déficits do balanço de pagamentos e, no longo prazo, remodelar a estrutura da economia brasileira. Propunha, deste modo, esforços que visassem à diversificação da produção nacional, com destaque para o desenvolvimento do setor manufatureiro: "Não se iludam os homens que têm nas mãos os destinos do país, a solução do café e da lavoura é parcial e não terá o alcance desejado se não adotarmos uma política econômica que defenda, incremente e avigore nossas indústrias" (Correa, 1903, p. 21).

Ainda assim, Correa mostrava-se levemente inclinado à defesa das indústrias que processassem matérias-primas (como a fiação) em detrimento das que trabalhassem com produtos já acabados (a tecelagem, por exemplo). O autor também conferia ênfase às indústrias de base - "cuja utilidade na vida industrial dos povos não se pode medir" (Correa, 1903, p. 209) - em virtude das facilidades de se explorar os recursos minerais que abundavam o território brasileiro.

Sua defesa intransigente da ação estatal na luta pela industrialização não pressupunha, porém, medidas de maior ousadia no campo fiscal. Conforme ressalta Fonseca (2008), Correa defendia a austeridade em termos de política econômica, rechaçando o déficit público como meio de fomento à atividade empresarial. Esta prerrogativa seria encontrada no discurso de outros atores, especialmente os papelistas e industrialistas.

Dentre os diversos motivos pelos quais uma nação deveria empenhar esforços em industrializar a sua economia, Correa sumarizava o seu quase proselitismo de forma lacônica: apenas a indústria, enfim, seria capaz de lograr a "independência nacional de um país novo". Tomando-se como exemplo as nações que já haviam realizado a sua revolução burguesa-industrial, o autor delegava a prosperidade destes países à "superioridade do estado econômico complexo e a solidariedade das indústrias de produção".

A via para se alcançar este patamar mais elevado de desenvolvimento passaria obrigatoriamente pelos instrumentos de política pública, como a concessão de prêmios, a preferência nacional nas licitações públicas e, principalmente, o protecionismo alfandegário.

\subsection{A proteção tarifária: abrangência e utilidade}

O meio pelo qual o nacionalismo de Serzedello Correa manifestou-se de modo mais eloquente foi através do protecionismo alfandegário. Para o autor, entre todos os instrumentos disponíveis para se fomentar o desenvolvimento econômico, tratava-se da tarifa o mais importante deles. Neste sentido, delegava à sua 
instrumentalização equivocada o atraso do país: "Que nossos desastres residem quase sempre no modo por que é confeccionada a nossa tarifa" (apud Machado, 1972, p. 140).

No posto de presidente da comissão central de tarifas da Câmara dos Deputados, Correa havia sido um dos principais responsáveis pela aprovação da reforma de 1896, tida como a mais protecionista desde a de 1879, proposta por Antonio Costa Pinto. Ao sugerir correlação obrigatória entre defesa tarifária e nacionalismo, o general considerava imperiosa a adoção de uma política protecionista por um governo que se concebesse efetivamente nacionalista: "Julgo imprescindível ao futuro engrandecimento de minha pátria a convicção da necessidade de uma política comercial eminentemente nacional, que comece reservando à nossa produção os nossos mercados internos" (Correa, 1903, p. 134). Ciente da centralidade da demanda interna como indutora do desenvolvimento da produção nacional, Serzedello fez da abolição dos impostos interestaduais outra de suas principais propostas de política econômica: "Essa medida é urgente e necessária, já em benefício da ordem política, já em proveito da ordem econômica".

A originalidade da política aduaneira por ele concebida assentava-se na proteção uniforme da produção nacional, não a restringindo apenas à controversa causa industrial. Para o autor, o governo haveria de acolher as demandas dos produtores brasileiros em sua totalidade: "Venho pregando a campanha de uma política econômica eminentemente nacional, de amparo, de proteção razoável às nossas indústrias, à nossa produção agrícola" (Correa, 1903, p. 109).

Desse modo, Serzedello conferia ao liberalismo características quase metafísicas, próprias àqueles que se atinham às ideias importadas da Europa: "Aconselham-nos o liberalismo somente os que amam mais utopias do que a pátria" (Correa, 1903, p. 138). Neste sentido, às práticas de livre-comércio adotadas pelo governo imperial em nome da estabilização dos preços o autor delegava a situação rudimentar das forças produtivas nacionais: "A política do 'laissez faire, laissez passer' [...] retardou o nosso progresso, que nos acorrentou no comércio ao regime dos monopólios e, na indústria, a só produzir o que havia de mais grosseiro e imperfeito" (Correa, 1903, p. 131).

A crítica à liberdade de comércio era personificada pela figura dos comerciantes importadores, muitos dos quais imigrantes europeus ${ }^{14}$. Partindo da premissa de que eram "profundamente antagônicos os interesses de um comércio

(14) O polêmico debate tarifário - do qual também se inteirava a população em geral, prejudicada pelo aumento dos preços decorrente da proteção alfandegária - era deste modo interpretado pelo autor: "Os que são contra o protecionismo dizem agir em nome dos consumidores: Fútil e mesquinho argumento! Não é, com efeito, o consumidor que faz o enriquecimento das nações, o seu poder, o bem-estar de todos seus habitantes; é, sim, o produtor, o que desenvolve os meios de trabalho, o que os cria e difunde" (Correa, 1903, p. 132). 
todo estrangeiro, que só quer viver da importação, e os interesses de uma indústria nacional" (Correa, 1903, p. 77), o autor condenava com veemência a facilidade com que os produtos importados dominavam o mercado interno ${ }^{15}$ :

Não é pelo aumento de importação, não é conservando-nos tributários em tudo do estrangeiro, que desenvolveremos a nossa riqueza, que haveremos de avigorar o nosso progresso, que aumentaremos a nossa produção, e é certo que sem uma sólida e crescente atividade nacional na ordem econômica seremos sempre um país empobrecido, sem nervos e sem sangue (Correa, 1903, p. 258).

A já citada política tarifária empregada ao longo do século XIX era descrita por Correa como uma falsa tentativa de fomento à atividade industrial brasileira dado o objetivo unicamente fiscal a ela subjacente: "Deixemos hipocritamente aparentar que defendemos o interesse nacional quando de fato o que fazemos é defender os interesses do comércio estrangeiro, não no que ele merecidamente deve ser atendido, mas naquilo que importa no sacrifício do nosso futuro e dos altos destinos da nossa pátria" (Correa, 1903, p. 132).

E foi justamente essa política equivocada que teria impelido o país, no alvorecer do regime republicano, à necessidade de importar "até bolachinhas e mostarda inglesa". Daí a sua convicção de ter sido "a política de abandono de nossas indústrias, de proteção a tudo o que era estrangeiro e importado, que retardou o nosso progresso material, que impediu o nosso desenvolvimento industrial e na própria indústria agrícola nos deixou viver no regime da rotina e do atraso" (Correa, 1903, p. 131).

O protecionismo alfandegário não se apresentava, nesse contexto, como uma política totalmente original e inovadora. Correa recorria exaustivamente ao exemplo dos países europeus - em especial, o da Inglaterra -, os quais se utilizaram fartamente de políticas de proteção antes de pregar o liberalismo às nações com as quais mantinham relações comerciais. Foi apenas após ter se tornado a principal economia industrial do planeta e a "senhora dos mares" que a Grã-Bretanha passou a incitar as vantagens ricardianas como política mais adequada para o desenvolvimento dos países subalternos (Correa, 1919, p. 38).

Sem uma política efetivamente protecionista, e "sob o regime de leis absurdas", seria inviável para o Brasil tornar-se uma nação verdadeiramente autônoma, de modo que o país haveria de continuar a ser, destarte, o que sempre havia sido: "Um povo colonizado, uma infeliz colônia das nações estrangeiras" (Correa, 1903, p. 170).

(15) Não raras foram as oportunidades em que o autor beirava a panfletagem com colocações de contornos chauvinistas, tais como: "Nós estamos em um país em que as preferências por tudo o que é estrangeiro é uma verdadeira moléstia" (apud Machado, 1972, p. 137). 
Em momentos de exacerbação retórica, Correa não se furtava de atacar impetuosamente os políticos que se mostravam favoráveis à retirada dos direitos de importações sobre determinados produtos, principalmente os que contassem com similares nacionais: "Seria um erro gravíssimo, seria a morte dessa indústria [papeleira], o aniquilamento do trabalho nacional que ao se exerce uma prova de nossa imbecilidade" (Correa, 1903, p. 226); "Só a completa ignorância ou coisa pior que isso, só a falta de patriotismo e a nenhuma preocupação de interesse público e nacional nos podem explicar esses atos de verdadeira imbecilidade" (Correa, 1903, p. 274); "Diminuir a tarifa sobre as indústrias de massa alimentícia não seria a meu ver, um erro, seria mesmo um crime" (Correa, 1903, p. 229).

Embora claramente favorável à adoção de uma política tarifária protecionista, Serzedello receitava moderação ao gestor público que dela se utilizasse. Assim como condenava o liberalismo comercial, reprovava com igual veemência o que ele denominou de "proibitismo de autossuficiência" (apud Luz, [1960] 1975, p. 80). De acordo com o autor, havia uma série de estabelecimentos que se fizeram viáveis dispensando a proteção aduaneira. Favorecer essas empresas seria prejudicar o consumidor brasileiro, o qual se via desnecessariamente "coagido a aceitar o mau produto, ou a pagar muito mais caro o bom, porque este é onerado em benefício daquele" (Correa, 1893, p. 126).

Desse modo, Correa reconhecia os favores provenientes das boas práticas de comércio internacional, tido por ele como "uma instituição de grande valor para os povos, pois movimenta as riquezas e põe ao alcance do consumidor tudo o que ele precisa", configurando, assim, "uma grande fonte de atividade e progresso humanos" (Correa, 1919, p. 36). Não ignorava, por fim, as necessidades fiscais do Tesouro público, satisfeitas, àquela época, em quase três quartos de sua totalidade pela renda gerada nas alfândegas, de modo que uma política que aviltasse as importações não seria outra medida que um "desserviço à nação" (Correa, 1893, p. 126).

A política aduaneira, portanto, responderia pelo principal instrumento de que um governo cônscio de suas responsabilidades pátrias deveria utilizar-se para não apenas ensejar o desenvolvimento de seu parque industrial, como também coordenar o processo de independência econômica indispensável aos países subdesenvolvidos os quais desejassem livrar-se do jugo estrangeiro.

\section{Considerações finais}

A despeito dos diferentes momentos por que passou e das distintas nuances que sempre a caracterizaram, a causa nacionalista não se notabilizou apenas por suas reivindicações próprias, mas também pelo embasamento que ofereceu a diversas outras manifestações políticas e intelectuais. Não se deve a outro motivo a sua 
consagração no prenome na ideologia que, aliada a outras ideias, viria posteriormente a formar: o "nacional"- desenvolvimentismo.

Das revoltas nativistas que se opunham à imposição colonial à luta pósIndependência pela emancipação econômica do país, a formação do sentimento de nação que permeou os movimentos patrióticos veio a desembocar no "nacionalismo republicano", do qual Serzedello Correa fez-se um de seus principais propagandistas.

Personagem com participação direta no golpe que encerrou o regime monárquico em 1889, Correa atuou como um verdadeiro primeiro-ministro do governo de Floriano Peixoto. Responsável pela concepção das políticas intervencionistas pró-industrialização deste período, consagrou-se pela defesa enfática da nacionalização da oferta de bens e serviços comercializados no Brasil. Militar de manifesta tradição positivista, enxergava na atuação do Estado o meio mais adequado de se coordenar os instrumentos necessários para o desenvolvimento do país.

Ao contribuir para a sistematização de uma corrente de pensamento que havia muito se expressava através de movimentos revoltosos, Serzedello antecipava o propósito de medidas nacionalistas que visassem ao amparo dos interesses pátrios, tal qual a política desenvolvimentista adotada décadas mais tarde. A concepção harmônica entre os diferentes segmentos produtivos, aliada à intransigência acerca da nacionalização das riquezas brasileiras discerniam o projeto de Correa em relação ao dos demais autores nacionalistas.

Consubstanciava a sua posição uma enfática defesa de políticas tarifárias protecionistas para toda a produção nacional, com destaque para o setor manufatureiro - tido por ele como único capaz de superar a condição de atraso da economia brasileira. A essa visão somar-se-ia a atuação dos advogados da indústria, cujas causas apresentavam expressiva intersecção com a agenda nacionalista.

\section{Referências bibliográficas}

BACKES, Ana Luiza. Nacionalismo no Congresso Brasileiro no início da República. Cadernos Aslegis, Brasília, n. 44, p. 93-110, set./dez., 2011.

BENTIVOGLIO, Julio C. O império das circunstâncias: o Código Comercial e a política econômica imperial (1840-1860). 2002. Tese (Doutorado)-Faculdade de Filosofia, Letras e Ciências Humanas, Universidade de São Paulo, São Paulo, 2002.

BOSI, Alfredo. Dialética da colonização. São Paulo: Companhia das Letras, 2001.

CARVALHO, José Murilo de. A formação das almas: o imaginário da República no Brasil. São Paulo: Cia. das Letras, 1990. 
CORREA, Inocencio Serzedello. Relatório Ministério das Relações Exteriores. Rio de Janeiro: Imprensa Nacional, 1892.

CORREA, Inocencio Serzedello. Relatório Ministério da Fazenda. Rio de Janeiro: Imprensa Nacional, 1893.

CORREA, Inocencio Serzedello. O problema econômico no Brasil. Rio de Janeiro: Imprensa Nacional, 1903.

CORREA, Inocencio Serzedello. Discurso sobre a Caixa de Conversão. Rio de Janeiro: Imprensa Nacional, 1906.

CORREA, Inocencio Serzedello. Elementos de economia política. [s.n.t], 1919.

CORRÊA, Maria Letícia. O debate de idéias econômicas na implantação da República no Brasil: progresso, modernização e construção da nação. In: SIMPÓSIO NACIONAL DE HISTÓRIA, 13., Rio de Janeiro, 2008.

COSTA, Emília V. da. Introdução ao estudo da emancipação política. In: MOTA, Carlos Guilherme da (Org.). Brasil em perspectiva. 15 ed. São Paulo: Difel, 1982.

COUTINHO, Carlos Nelson. Cultura brasileira: um intimismo deslocado, à sombra do poder? Cadernos de Debate, São Paulo, n. 1, 1976.

FERNANDES, Florestan. A revolução burguesa no Brasil: ensaio de interpretação sociológica. 3. ed. Rio de Janeiro: Guanabara, 1987.

FONSECA, Pedro Cezar D. Gênese e precursores do desenvolvimentismo no Brasil. Revista Pesquisa \& Debate, São Paulo, v. 15, n. 2 (26), p. 225-256, 2004.

FONSECA, Pedro Cezar D. A controvérsia entre metalismo e papelismo e a gênese do desenvolvimentismo no Brasil. In: ENCONTRO NACIONAL DE ECONOMIA, 36., Salvador: Anpec, 2008.

FONTOURA, João N. da. Serzedelo Correia, uma figura da República. In: CORREA, Innocencio Serzedello. Uma figura da República: páginas do passado. Rio de Janeiro: F. Bastos, 1959.

FRANCO, Maria Sylvia de C. As idéias estão em seu lugar. Cadernos de Debate, São Paulo, Brasiliense, n. 1, 1976.

HOLANDA, Sergio B. de. Raízes do Brasil. São Paulo: Companhia das Letras, 2006.

LEME, Marisa S. A ideologia dos industriais brasileiros (1919-1945). Petrópolis: Vozes, 1978.

LESSA, Carlos Francisco Theodoro M. R. de. Nação e nacionalismo. Estudos Avançados, São Paulo, v. 22, n. 62, 2008. 
LIMA, Heitor. Significação do nacionalismo. In: SCHWARTZMAN, Simon (Org.). Pensamento nacionalista e os "Cadernos do nosso tempo". Brasília: Editora UnB, 1988.

LUIS NETO, Washington. Introdução. In: CORREA, Innocencio Serzedello. $O$ problema econômico no Brasil. Brasília: Senado Federal, 1980.

LUZ, Nícia V. A luta pela industrialização no Brasil. São Paulo: Alfa Omega, 1975. MACEDO, Ubiratan B. O liberalismo moderno. São Paulo: Ed. Massao Ohno, 1997.

MACHADO, Eurico S. Um Republicano. A vida de Inocêncio Serzedello Corrêa. Rio de Janeiro: CEA, 1972.

NOGUEIRA, Marco A. As desventuras do liberalismo: Joaquim Nabuco, a Monarquia e a República. Rio de Janeiro: Paz e Terra, 1984.

PINHEIRO, Manoel Carlos. Innocencio Serzedello Corrêa: vida e obra. Rio de Janeiro: IPP, 2008.

PRADO JÚNIOR, Caio. Evolução política do Brasil e outros estudos. São Paulo: Brasiliense, 1957.

REGO, Clovis M. Serzedello Corrêa. Homem de Pensamento. Belém: TCE-PA, 1989.

RICUPERO, Bernardo. Da formação à forma. Ainda as “idéias fora do lugar”. Lua Nova, São Paulo, n. 73, p. 59-69, 2008.

ROUANET, Sérgio Paulo. Contribuição para a dialética da volubilidade. Revista da USP, São Paulo, n. 9, 1991.

SAES, Guillaume A. M. de. Militares e desenvolvimento no Brasil: uma análise comparada dos projetos econômicos da oficialidade republicana de fins de século XIX, do tenentismo e da cúpula militar do Estado Novo. 2011. Tese (Doutorado)Faculdade de Filosofia, Letras e Ciências Humanas, Universidade de São Paulo, São Paulo, 2011.

SALOMÃO, Ivan C. O desenvolvimento em construção: um estudo sobre a préhistória do pensamento desenvolvimentista brasileiro. 2013. Tese (Doutorado) Universidade Federal do Rio Grande do Sul, Porto Alegre, 2013.

SCHULZ, John. O exército na política. Origens da intervenção militar - 1850-1894. São Paulo: Edusp, 1994.

SCHWARZ, Roberto. As idéias fora do lugar. In: SCHWARZ, Roberto. Ao vencedor as batatas: forma literária e processo social nos inícios do romance brasileiro. São Paulo: Paz e Terra, 2001. 
SODRÉ, Nelson W. Raízes históricas do nacionalismo brasileiro. Rio de Janeiro: Instituto Superior de Estudos Brasileiros, 1960.

WEFFORT, Francisco C. Formação do pensamento político brasileiro. Ideias e personagens. São Paulo: Atica, 2006. 